Piotr KAMIŃSKI ${ }^{1}$, Nikodem KOWALSKI ${ }^{2}$, Mikołaj POLOCZEK ${ }^{3}$, Artur PEZDA ${ }^{4}$, Iga DROBINA ${ }^{5}$

Opiekun naukowy: Robert DROBINA ${ }^{6}$

DOI: https://doi.org/10.53052/9788366249837.32

\title{
PROJEKT DYDAKTYCZNEGO MANIPULATORA
}

Streszczenie: W artykule zaprezentowano zastosowanie i rodzaje robotów. Przedstawiono wykonamy projekt manipulatora do nauki robotyki, który obejmował wykonanie konstrukcji mechanicznej, dobór osprzętu elektronicznego oraz stworzenie interfejsu graficznego dostępnego na przeglądarce www.

Słowa klucze: robot, sterowanie, projektowanie, klasyfikacja

\section{TEACHING MANIPULATOR PROJECT}

\begin{abstract}
The article presents the application and types of robots. The project of a robotic manipulator was presented, which included the execution of a mechanical structure, selection of electronic equipment and the creation of a graphical interface available in a web browser.
\end{abstract}

Key words: robot, control, design, classification

\section{Cel i zakres pracy}

Celem niniejszej pracy było przedstawienie klasyfikacji robotów ze względu na ich zastosowanie, a także zaprezentowanie projektu manipulatora dydaktycznego 5osiowego, który służy jako model dydaktyczny do nauki programowania robotów w technikum jednej z Bielskich szkół średnich.

Zakres pracy obejmował zaprojektowanie poszczególnych części składowych manipulatora w programie do rysunku 3D następnie wykonanie części mechanicznej,

\footnotetext{
${ }^{1}$ mgr inż. Akademia Techniczno-Humanistyczna w Bielsku-Białej, Wydział Budowy Maszyn i Informatyki, specjalność: Inżynieria Produkcji email: piotr-pio-kam@wp.pl

${ }^{2}$ Uczeń Zespołu Szkół Elektronicznych, Elektrycznych i Mechanicznych w Bielsku-Białej

${ }^{3}$ Uczeń Zespołu Szkół Elektronicznych, Elektrycznych i Mechanicznych w Bielsku-Białej

${ }^{4}$ Uczeń Zespołu Szkół Elektronicznych, Elektrycznych i Mechanicznych w Bielsku-Białej

${ }^{5}$ Uniwersytet Śląski w Katowicach, Wydział Prawa i Administracji, email: iga.drobina@gmail.com

${ }^{6}$ prof. ATH dr hab. inż., Akademia Techniczno-Humanistyczna w Bielsku-Białej, Wydział Budowy Maszyn i Informatyki, email: rdrobina@ath.bielsko.pl
} 
dobór układu zasilania, sterowania oraz napisanie aplikacji służącej do programowania manipulatora.

\section{Wstęp}

Manipulacyjne roboty przemysłowe łączą w sobie elementy elektroniki, mechaniki, informatyki i automatyki. Połącznie tych dziedzin umożliwiło wykorzystanie robotów w bardzo dużym zakresie zarówno w przemyśle, medycynie, militariach, rolnictwie. W przemyśle wykorzystywane są do wytwarzania elementów służących do budowy maszyn, urządzeń, części samochodowych. Zastępują one $\mathrm{z}$ powodzeniem pracę wykonywaną przez pracownika cechującą się:

- dużą powtarzalnością wykonywanych ruchów,

- monotonną pracy,

- pracą wymagającą wymuszonej pozycji ciała,

- pracą narażoną na długotrwałe oddziaływanie czynników szkodliwych tj. promieniowanie nadfioletowe powstałe na skutek spawania metali.

Dzięki zastosowaniu robotów przemysłowych prowadzony proces produkcyjny w zakładzie przemysłowym staje się wydajniejszy i zwiększa się produktywność. Roboty przemysłowe mają szerokie możliwości technologiczne, w tym utrzymanie wysokiej dokładności ruchu oraz sztywności.

\section{Klasyfikacja robotów ze względu na ich zastosowanie}

Ponieważ coraz więcej robotów jest projektowanych do określonych zadań, ta metoda klasyfikacji staje się coraz bardziej istotna. Na przykład wiele robotów jest zaprojektowanych do prac montażowych, które mogą nie być łatwe do przystosowania do innych zastosowań. Nazywa się je „robotami montażowymi”. W przypadku spawania liniowego niektórzy dostawcy dostarczają kompletne systemy spawalnicze z robotem, tj. Sprzęt spawalniczy wraz z innymi urządzeniami do obsługi materiałów, takimi jak obrotnice itp., Jako zintegrowana jednostka. Taki zintegrowany system robotyczny nazywany jest „robotem spawalniczym”, mimo że jego manipulator można dostosować do różnych zadań. Niektóre roboty są specjalnie zaprojektowane do manipulowania ciężkimi ładunkami i są oznaczone jako „roboty do dużych obciążeń”.

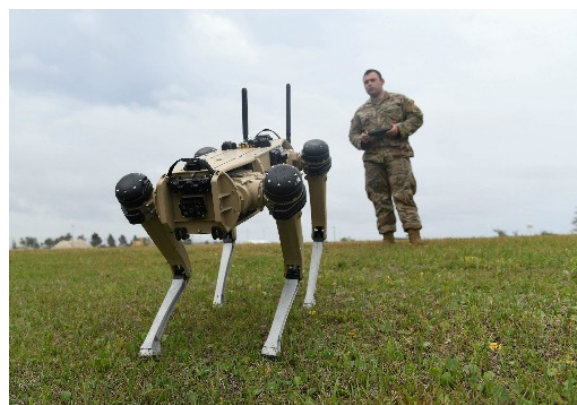

Rysunek 1. Robot wojskowy [1]

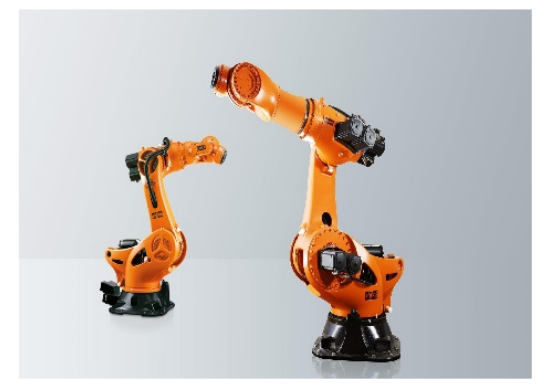

Rysunek 2. Robot przemystowy [2] 
Roboty wojskowe (rys.1.) - przeznaczonymi do zastosowań wojskowych, od transportu po poszukiwania i ratownictwo oraz atak [1].

Roboty przemysłowe (rys.2.) - coraz częściej wykorzystywane w produkcji (od lat 60. XX wieku). Według danych Robotic Industries Association w USA, w 2016 r. Głównym odbiorcą robotów przemysłowych był przemysł motoryzacyjny z 52\% sprzedaży ogółem. [W przemyśle samochodowym mogą stanowić ponad połowę ,,siły roboczej". Istnieją nawet fabryki "wyłączane na światło", takie jak fabryka klawiatur IBM w Teksasie, która została w pełni zautomatyzowana już w 2003 roku [2].

Co-boty (roboty współpracujące) (rys.3.) - czyli roboty współpracujące, to roboty przeznaczone do bezpośredniej interakcji człowieka z robotem w ramach wspólnej przestrzeni lub tam, gdzie ludzie i roboty znajdują się w bliskiej odległości. Aplikacje Cobota kontrastują $\mathrm{z}$ tradycyjnymi zastosowaniami robotów przemysłowych, w których roboty są odizolowane od kontaktu z człowiekiem. [1] Bezpieczeństwo Cobota może polegać na lekkich materiałach konstrukcyjnych, zaokrąglonych krawędziach i nieodłącznym ograniczeniu prędkości i siły lub na czujnikach i oprogramowaniu, które zapewnia bezpieczne zachowanie [3].

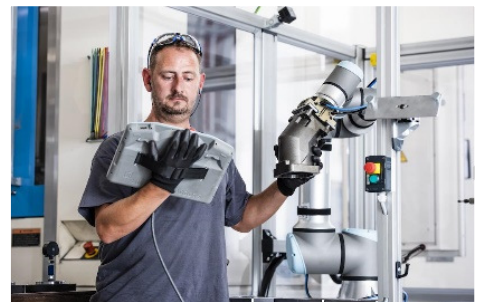

Rysunek 3. Co-bot [3]

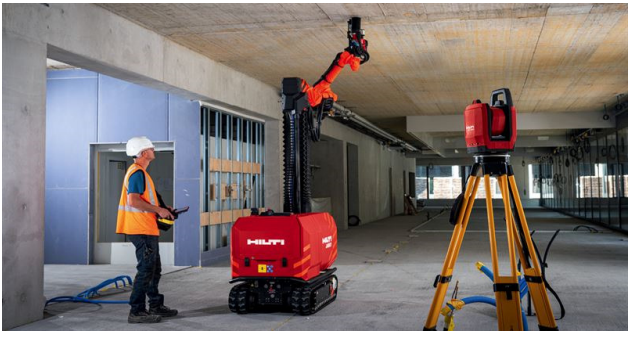

Rysunek 4. Robot konstrukcyjny [4]

Roboty konstrukcyjne (rys.4.) - wykorzystywane w budowie konstrukcji nośnych budynków, wykonywaniu i działań z zakresu prac budowlanych. Można je podzielić na trzy typy: roboty tradycyjne, ramię robota i egzoszkielet robota [4].

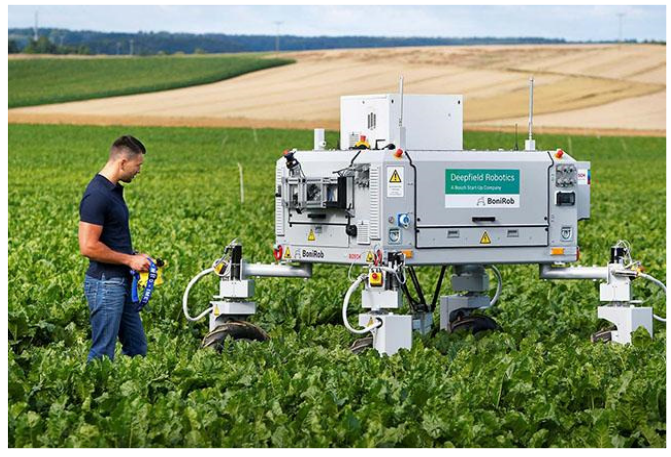

Rysunek 5. Robot rolnniczy [5]

Roboty rolnicze (AgRobots) (rys.5.) - Wykorzystanie robotów w rolnictwie jest ściśle powiązane $\mathrm{z}$ koncepcją rolnictwa precyzyjnego wspomaganego sztuczną inteligencją 
i wykorzystaniem dronów. Badania z lat 1996-1998 dowiodły również, że roboty mogą wykonywać zadania pasterskie [5].

Roboty medyczne różnych typów (rys.6.) (np. Da Vinci Surgical System i Hospi) [6].

Automatyka kuchenna (rys.7.) - przykłady automatyzacji kuchni to Flippy (hamburgery), Zume Pizza (pizza), Cafe X (kawa), Makr Shakr (koktajle), Frobot (mrożone jogurty) i Sally (sałatki) ich zadaniem jest pomoc w sporządzaniu posiałków[7].

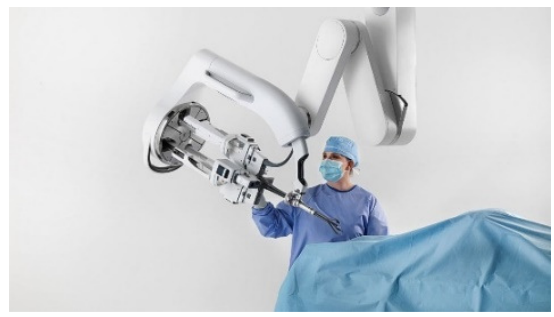

Rysunek 6. Robot medyczny [6]

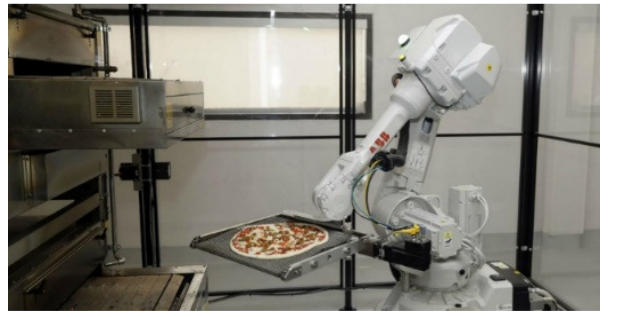

Rysunek 7. Robot przemystowy dedykoway dla przemystu gastronomicznego [7]

Sportowa walka robotów (rys.8.) - hobby lub wydarzenie sportowe, w którym dwa lub więcej robotów walczy na arenie, aby się wzajemnie unieszkodliwić. Ta dyscyplina rozwinęła sięw latach 90 [8].

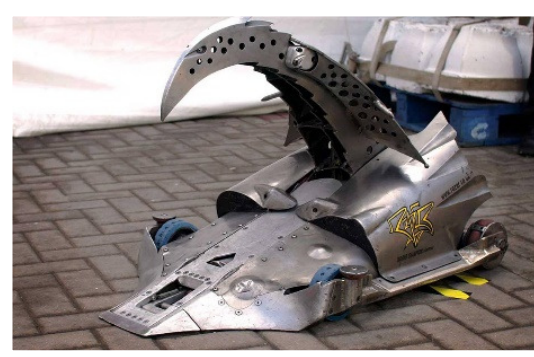

Rysunek 8. Robot na walki robotów [8]

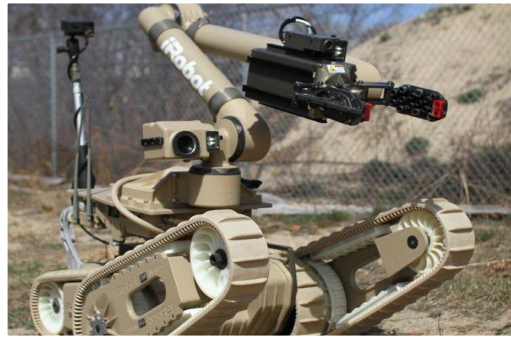

Rysunek 9. Robot czyszczacy [9]

Roboty czyszczące (rys.9.) - To robot, którego zadaniem jest oczyszczanie zanieczyszczonych obszarów, z odpadów toksycznych i niebezpiecznych [9].

Roboty domowe (rys.10.) - to roboty wykonujące codzienne obowiązki domowe, typu robot czyszczący, robot koszący itd. [10]. 


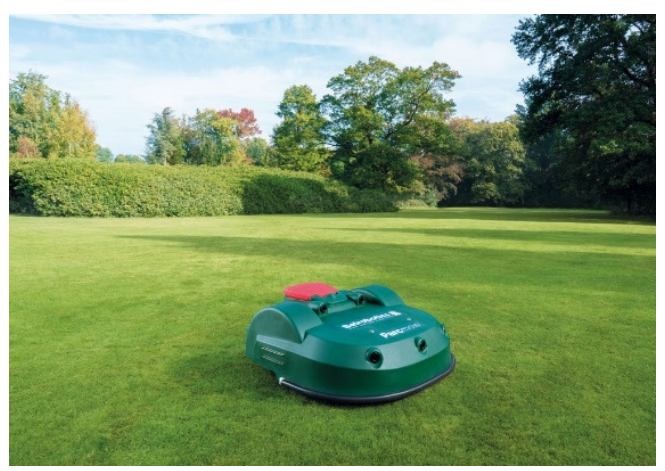

Rysunek 10. Robot koszacy trawe [10]

Nanoroboty (rys.11.) - to wschodząca dziedzina technologii tworząca maszyny lub roboty, których komponenty są na skali nanometra (10-9 metrów) lub w jej pobliżu. Mówiąc dokładniej, nanorobotyka (w przeciwieństwie do mikrorobotyki) odnosi się do dyscypliny inżynierii nanotechnologicznej polegającej na projektowaniu i budowie nanorobotów, z urządzeniami o wielkości od 0,1 do 10 mikrometrów i zbudowanymi z nanoskali lub komponentów molekularnych. Terminy nanobot, nanoid, nanit, nanomaszyna lub nanomit zostały również użyte do opisania takich urządzeń, które są obecnie w fazie badań i rozwoju [11].

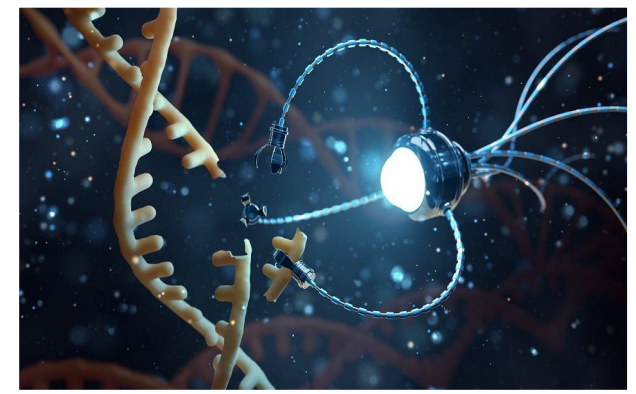

Rysunek 11. Nanorobot [11]

Robotyka ławicy (rys.12.) - podejście do koordynacji wielu robotów jako systemu, który składa się z dużej liczby przeważnie prostych robotów fizycznych. Przypuszcza się, że pożądane zachowanie zbiorowe wyłania się z interakcji między robotami oraz interakcji robotów $\mathrm{z}$ otoczeniem. Podejście to pojawiło się na polu sztucznej inteligencji roju, a także biologicznych badań owadów, mrówek [12]. 


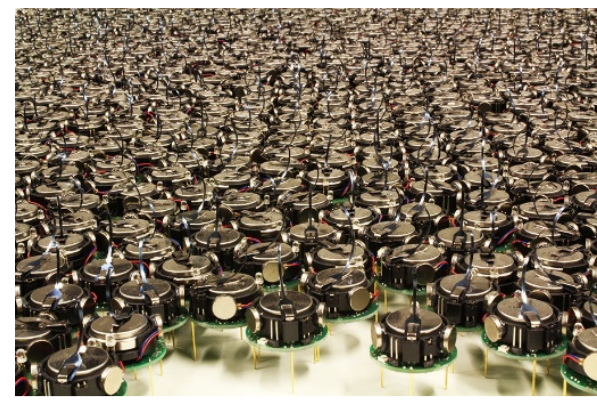

Rysunek12. Roboty ławica [12]

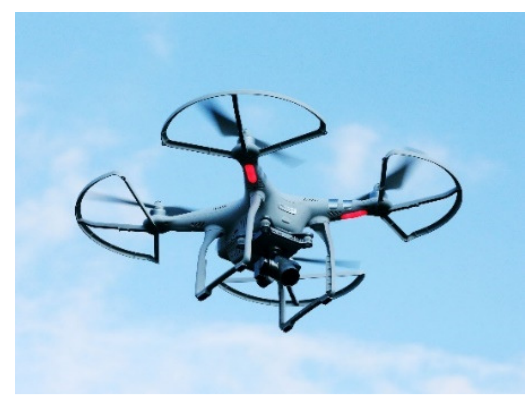

Rysunek 13. Dron [13]

Autonomiczne drony (rys.13) - Bezzałogowy statek powietrzny (UAV). Lot UAV może działać z różnym stopniem autonomii: albo pod zdalnym sterowaniem przez człowieka, albo autonomicznie przez komputery pokładowe, zwane autopilotem [13].

\section{Projekt manipulatora dydaktycznego pięcioosiowego}

\subsection{Projekt części mechanicznej}

Poszczególne części składowe manipulatora zostały wykonane w programie AutoCAD oraz wspomagane poprzez Fusion 360 . Na ich podstawie zostały wykonane części ze stali 8HMJ, aluminium PA6, natomiast obudowy na drukarce 3D typu FDM - użyto w tym celu materiału PLA. Wykonane elementy aluminiowe zostały zabezpieczone przed utlenianiem oraz przebiciami prądu na korpus za pomocą Anodowania. Części stalowe zostały zabezpieczone poprzez galwanizacje.

Główny element konstrukcyjny robota stanowi jego podstawa, która została zaprojektowana tak, aby można było ją na trwałe połączyć z podłożem lub zamocować na jezdnej platformie. Osprzęt dodatkowy na platformie został konstrukcyjnie przemyślany i dobrany, aby był on w pełni demontowany ułatwiając serwisowanie oraz wymianę elementów (rys.14.).

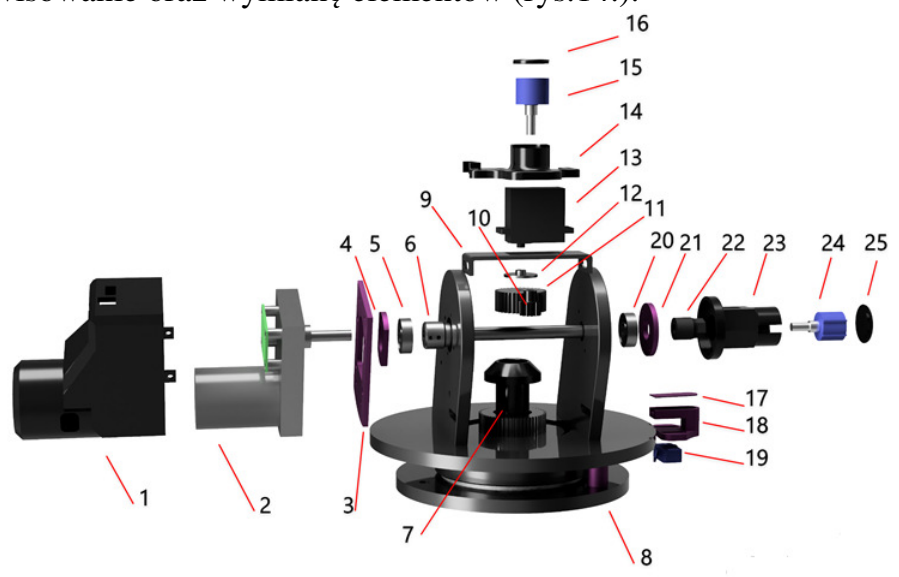

Rysunek 14. Robot dydaktyczne 
Gdzie: Podstawa robota 1 - Osłona silnika, 2 - Silnik servo UART, 3 - Adapter silnika, 4 - Ostona tożyska (strona napędowa), 5 - Łożysko 608 2RS, 6 - Wat napędowy, 7 - Prowadnica przewodów, 8 - Podstawa, 9 - Adapter silnika, 10 - Zębatka PLA z10, 11 - Koło zębate ALU z30 M1, 12 - Orczyk silnika, 13 - Silnik servo, 14 - Adapter czujnika, 15 - Potencjometr wieloobrotowy, 16 - Ostona adaptera, 17 - Ostona krańcówki, 18 - Korpus krańcówki, 19 Krańcówka, 20 - Łożysko 608 2RS, 21 - Osłona tożyska (strona czujnika), 22 - Sprzegło, 23 - Korpus czujnika, 24 - Potencjometr wieloobrotowy, 25 - Ostona czujnika,

Przykładowy rysunek złożeniowy części podstawy robota tj. płyty mocującej do podłoża na (rys.15.) oznaczonej numerem 8 przedstawiono na (rys.15.)
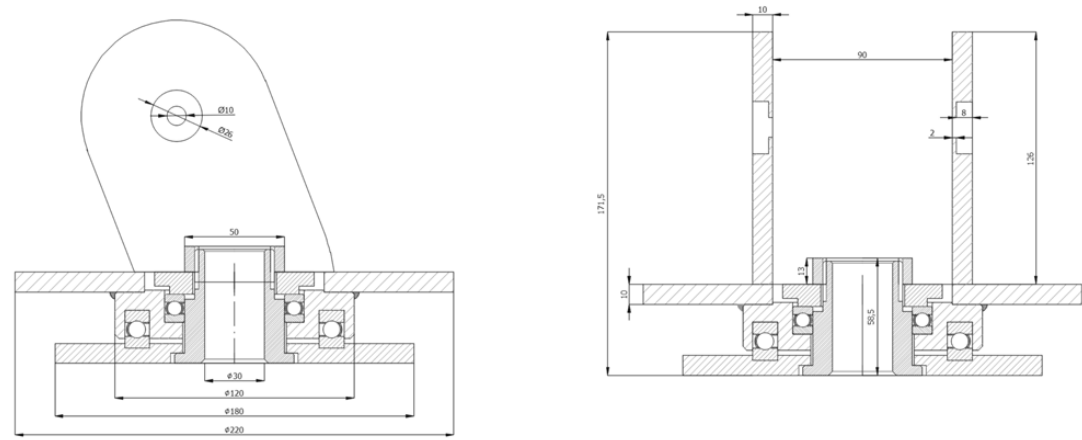

Rysunek 15. Ptyta mocująca do podtoża

Robot składa się z podstawy, 2 ramion oraz głowicy. Pierwsze ramię mocowane jest do podstawy i przedstawia je (rys. 16.). Ramię to przenosi największe obciążenia dlatego zdecydowano się na 90\% wypełnienie płyt usztywniających (8).

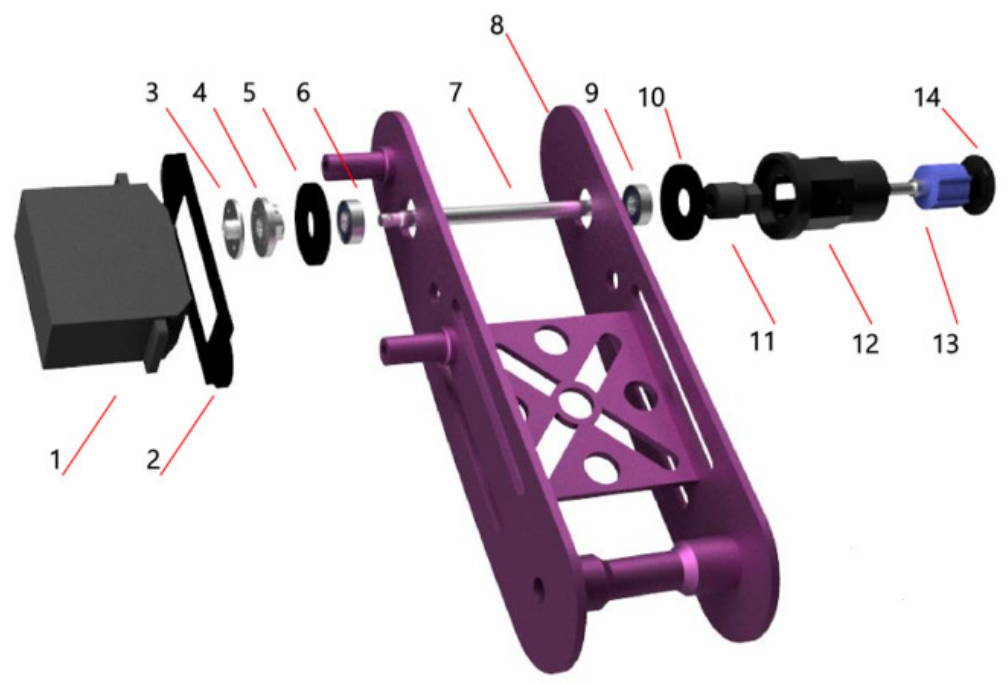

Rysunek 16. Ramie robota 
Gdzie: Ramię robota 1 - Silnik servo, 2 - Adapter silnika, 3 - Orczyk silnika, 4 Orczyk watu, 5 - Ostona tożyska (strona napędowa), 6 - Łożysko 608 2RS, 7 - Wat napędowy, 8 - Korpus pierwszego ramienia, 9 - Łożysko 608 2RS,

10 - Osłona łożyska (strona czujnika), 11 - Sprzęgło, 12 - Korpus czujnika, 13 - Potencjometr wieloobrotowy, 14 - Ostona czujnika.

Drugie ramię robota przedstawiono na (rys.17.). Odchudzone ramie, z wycięciami na tylnej części zostały tak wykonane, aby nadać wartości estetycznej konstrukcji. Założono, że ramię to swobodnie będzie obracać się o 170 stopni względem sworznia (7) (rys.17.) pozwoli to zwiększyć zakres roboczy manipulatora.

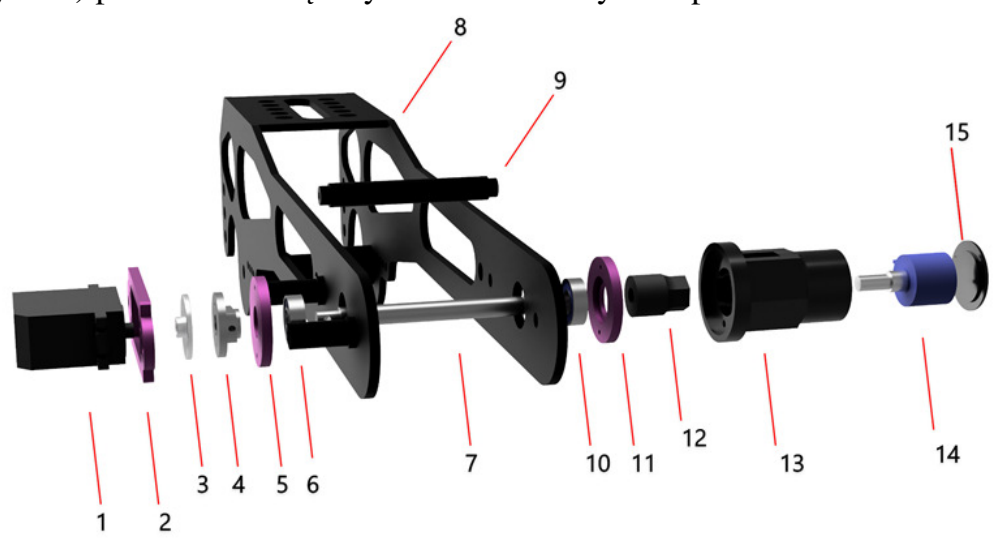

Rysunek 17. Drugie ramię robota

Gdzie: Ramię robota - 1 - Silnik servo, 2 - Adapter silnika, 3 - Orczyk silnika, 4 - Orczyk wału, 5 - Osłona łożyska (strona napędowa), 6 - Łożysko 608 2RS, 7 - Wat napędowy, 8 - Korpus drugiego ramienia, 9 - Usztywnienie korpusu, 10 - Łożysko 608 2RS, 11 - Ostona tożyska (strona czujnika), 12 - Sprzęgło, 13 - Korpus czujnika, 14 - Potencjometr wieloobrotowy, 15 - Ostona czujnika

Głowica robota została tak zaprojektowana, aby umożliwiała montaż uniwersalnego chwytaka rys. 18 .

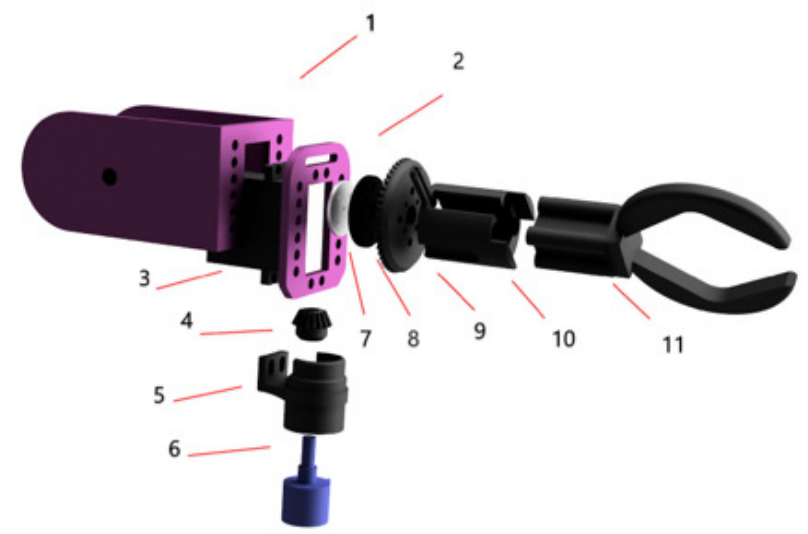

Rysunek 18. Głowica z chwytakiem 
Gdzie: Głowica 1 - Korpus głowicy, 2 - Adapter części operacyjnej, 3 - Silnik servo. 4 - Zębatka stożkowa z10 M1, 5 - Korpus czujnika, 6 - Potencjometr wieloobrotowy, 7 - Orczyk silnika, 8 - Adapter chwytaka, 9 - Zębatka stożkowa z30 M1, 10 - Ostona chwytaka, 11 - Chwytak

Dla tak przedstawionych poszczególnych elementów robota dokonano ich zestawiania w jeden rysunek złożeniowy (rys.19.).

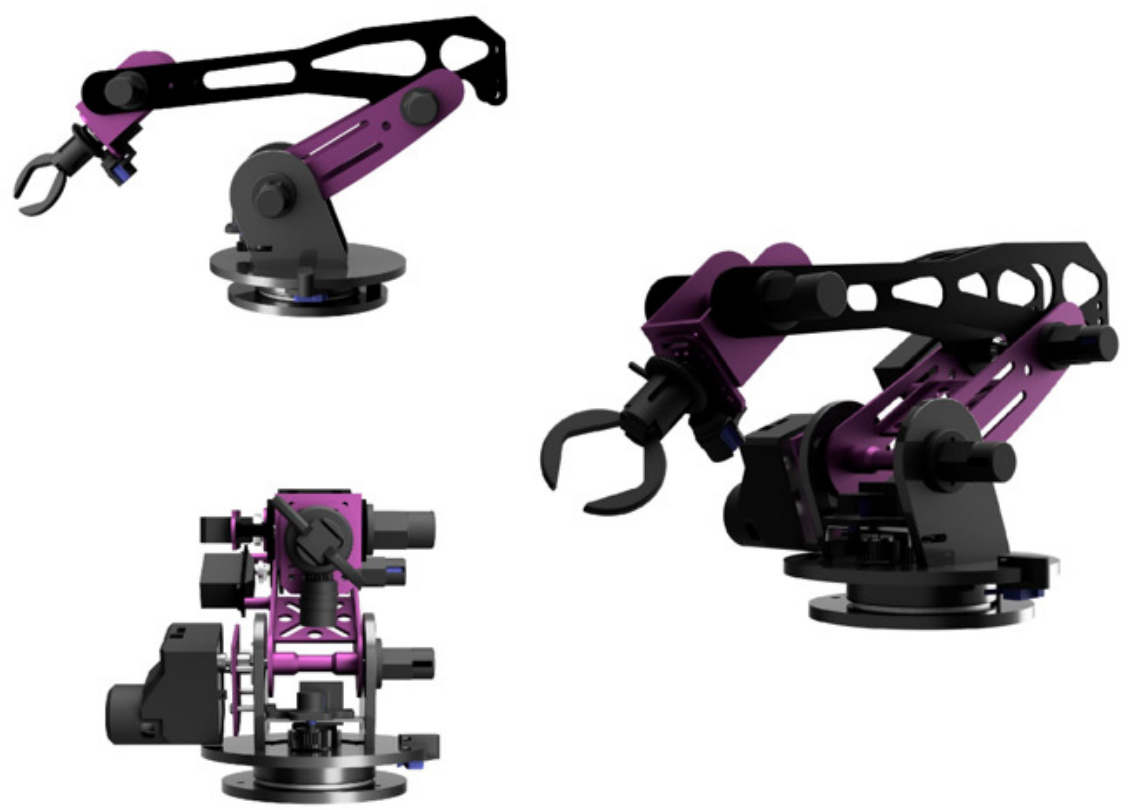

Rysunek 19. Wizualizacja robota

\subsection{Projekt części elektryczno-elektrycznej}

Podstawowym elementem części elektrycznej są silniki. Ich dobór opiera się na wyznaczeniu momentu znamionowego oraz prędkości obrotowej. W projekcie założono, że chwytak będzie wstanie podnieść ciężar o masie nie przekraczającej 0,5 kg. Przy obliczaniu momentu jaki powinny posiadać poszczególne silniki uwzględniono max wychylenie robota. Schematycznie przedstawia to (rys.20.). 


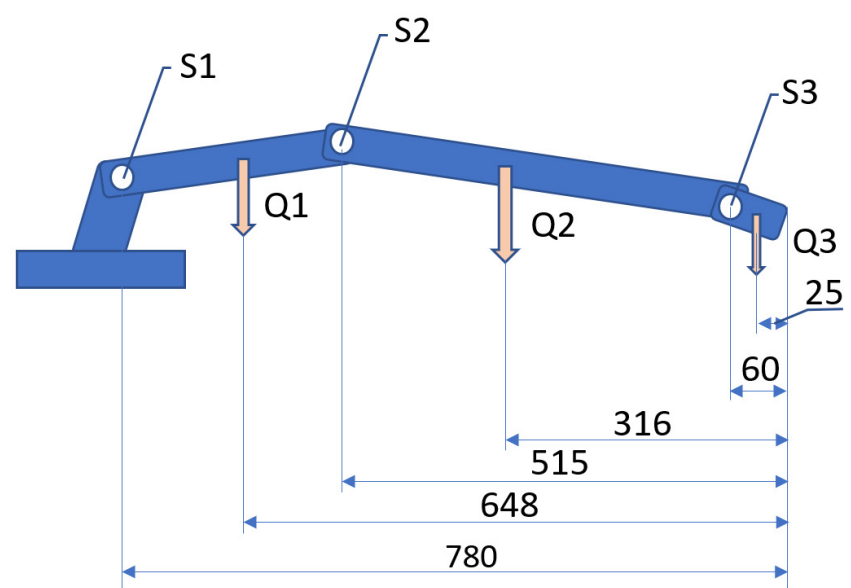

Rysunek 20. Model fizyczny sił działających na robota

Masy poszczególnych ramion robota wraz ze środkami ciężkości zostały wyznaczone w programie Fusion 360 na ich podstawie wyznaczono momenty poszczególnych Silników S1, S2, S3 (rys.20.). Założono dodatkowo że ruchy poszczególnych ramion robota będą odbywać się z małymi prędkościami dlatego w dalszej części pominięto siły bezwładności. Wyznaczenie minimalnego momentu na silniku S1, S2, S3 (rys.20.).

$$
\begin{aligned}
& M_{S 1}=Q_{4} \cdot 780, \mathrm{~mm}+Q_{3} \cdot 755, \mathrm{~mm}+Q_{2} \cdot 265, \mathrm{~mm}+Q_{1} \cdot 132, \mathrm{~mm}= \\
& 10,61 \mathrm{Nm} \\
& M_{S 2}=Q_{4} \cdot 515, \mathrm{~mm}+Q_{3} \cdot 490, \mathrm{~mm}+Q_{2} \cdot 199, \mathrm{~mm}=6,11 \mathrm{Nm}, \\
& M_{S 3}=Q_{4} \cdot 60, \mathrm{~mm}+Q_{3} \cdot 35, \mathrm{~mm}=0,44 \mathrm{Nm} .
\end{aligned}
$$

gdzie:

$M_{S 1}$ - minimalny moment silnika $\mathrm{S} 1$,

$M_{S 2}$ - minimalny moment silnika S2,

$M_{S 3}$ - minimalny moment silnika S3,

$Q_{4}=5 N$ - siła ciężkości podnoszonej masy $0,5 \mathrm{~kg}$,

$Q_{3}=4 N$ - siła ciężkości głowicy o masie $0,4 \mathrm{~kg}$,

$Q_{2}=7,9 N$ - siła ciężkości 2 ramienia o masie $0,79 \mathrm{~kg}$,

$Q_{1}=8 N$ - siła ciężkości 1 ramienia o masie $0,8 \mathrm{~kg}$.

Dla tak wyznaczonych momentów dobrano następujące silniki (rys.21.). 
S1

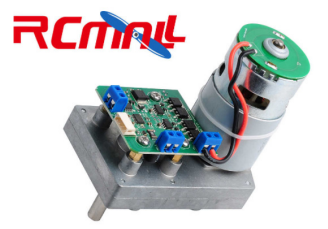

Specyfikacja:

Napięcie zasialania: $12 \mathrm{VDC}$

Zakres ruchu: od $0^{0}$ do $360^{\circ}$,

Typ: cyfrowe

Wymiary: 95,5 x 65 x 85mm

Częstotliwość pracy:

do $33 \mathrm{~Hz} / 1520 \mu \mathrm{s}$

Masa: $750 \mathrm{~g}$

Moment: dla 12V: $18 \mathrm{Nm}$

Prędkość: $0,18 \mathrm{~s} / 60^{\circ}$
S2

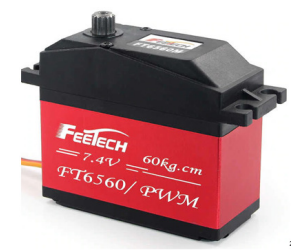

Specyfikacja:

Napięcie zasialania: od6V

do 7,4V DC,

Zakres ruchu: od $0^{0}$ do

$180^{\circ}$,

Typ: cyfrowe

Wymiary: 65,8 x 30,2 x

$57,4 \mathrm{~mm}$

Złącze konektor: JST

Częstotliwość pracy: do

$33 \mathrm{~Hz} / 1520 \mu \mathrm{s}$

Masa: $200 \mathrm{~g}$

Moment: dla 7,4V: 6,2Nm

Prędkość: $0,18 \mathrm{~s} / 60^{\circ}$
S3

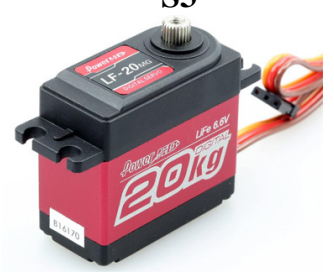

Specyfikacja:

Napięcie zasialania: od $4,8 \mathrm{~V}$ do $6 \mathrm{~V}$ DC,

Zakres ruchu: od $0^{0}$ do $270^{\circ}$,

Typ: cyfrowe

Wymiary: 40,7 x 20,5 x

$39,5 \mathrm{~mm}$

Złącze konektor: JST

Częstotliwość pracy:

do $33 \mathrm{~Hz} / 1520 \mu \mathrm{s}$

Masa: $60 \mathrm{~g}$

Moment: dla 4,8V: 1,61Nm

Prędkość: $0,18 \mathrm{~s} / 60^{\circ}$

\section{Rysunek 21. Specyfikacja zastosowanych silników [14]}

Osprzęt elektroniczny został tak dobrany, aby dostarczyć do silników odpowiednie napięcie oraz umożliwić sterowanie robotem. Układ elektroniczny składa się z:

- Raspberry Pi Zero W,

- Arduino Nano,

- $\quad$ sterownik PWM PCA9685,

- konwerter analogowo-cyfrowy ADS1015,

- $\quad$ sterownik UART FE-URT-1,

- sterownik silnika L9110S,

- $\quad$ konwerter poziomów logicznych dwukierunkowy BOB-12009,

- wyświetlacz LCD 2x16,

- potencjometr wieloobrotowy $10 \mathrm{k}$ Ohm,

- potencjometr liniowy 10k Ohm,

- serwo PowerHD LF-20MG-360,

- serwo PowerHD LF-20MG-270,

- serwo Feetech FT6560M,

- FEETECH SMS150 180kg.

Sercem układu jest RaspberryPi, które komunikuje się przez standard I2C ze sterownikiem pwm, przetwornikami analogowo-cyfrowymi oraz mikrokontrolerem Arduino które służy jako przetwornik A-C. Pozycje robota odczytywane są za pomocą potencjometrów, następnie sygnał konwertowany jest z analogowego na cyfrowy i trafia do RaspberryPi. Chwytakiem robota steruje się poprzez zmianę polaryzacji napięcia za pośrednictwem sterownika L9110 


\subsection{Projekt części programowania robota}

Program realizujący określone sekwencje ruchów robota został napisany w języku Python. Python to dynamiczny obiektowy język programistyczny, który jest łatwy w nauce i można go wykorzystać do tworzenia różnorakiego oprogramowania. Python rozprowadzany jest na otwartej licencji umożliwiającej zastosowanie go do zamkniętych komercyjnych projektów. W sieci dostępnych jest wiele przewodników, jak i dodatkowych bibliotek, czy narzędzi ułatwiających programowanie w tym języku. Python jest aktywnie rozwijany i posiada szerokie grono użytkowników na całym świecie i jest jednym z najpopularniejszych języków według różnego rodzaju metryk mierzących ilość tworzonych projektów, bibliotek i preferencji programistów [15].

Program został napisany w następujący sposób:

1. Plik wejściowy main.py tworzy instancję klasy RobotServer, która umożliwia wykorzystanie biblioteki Flask do uruchomienia serwera www. Dzięki użyciu rozszerzenia PERFUME kod Flask napisany jest obiektowo.

2. Po stworzeniu instancji serwera www z wykorzystaniem SOCKET.IO program uruchamia inicjację ustawień z pliku o nazwie config.json.

3. Skrypt inicjuję połączenie SOCKET.IO uruchamiając handler asynchroniczności EVENTLET

4. Wykorzystanie strony WWW do zarządzania robotem wymusza ustawienie parametru cors_allowed_origins na “*” czyli dowolny adres IP.

5. Skrypt tworzy instancję klasy Robot Controller umożliwiając sterowanie robotem.

6. Instancja klasy Robot Server konfigurowana jest parametrami pozwalającymi na komunikacje między kontrolerem i serwerem sieciowym.

7. Finalnie aplikacja uruchamia nasłuchiwanie na adresie 0.0.0.0 co pozwala na połączenie z każdgo urządzenia. Parametr debug=True umożliwia podgląd transmisji danych, nie powinien on być ustawiony na True podczas stałej pracy robota.

Część programu pliku konfiguracyjnego o nazwie confing.json przedstawiono na (rys.22.) Plik konfiguracyjny robota. Dzieli się on na sekcje pozwalające ustawić parametry pracy programu bez ingerencji w kod źródłowy, co jest założeniem napisanego kodu. Ustalamy tutaj takie ustawienia jak ustawienia serwomechanizmów, adresy i2c kontrolerów, długości fal PWM. 


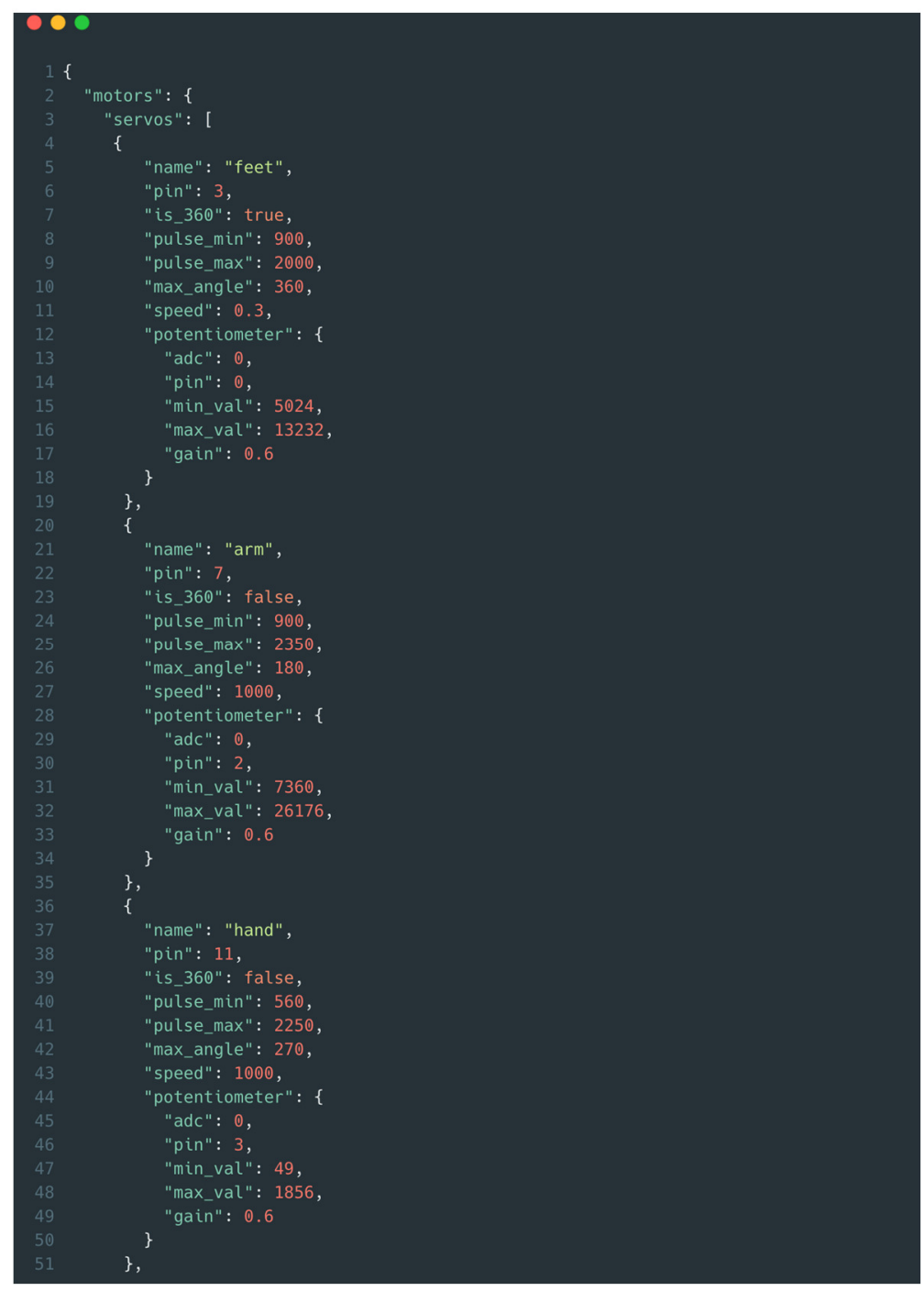

Rysunek 22. Programu pliku konfiguracyjnego

Dla tak stworzonego kodu stworzono graficzny panel sterujący dostępny z ustawień przeglądarki internetowej oraz $\mathrm{z}$ aplikacji mobilnej na telefon. Widok interfejsu przedstawiono na (rys.23.) 

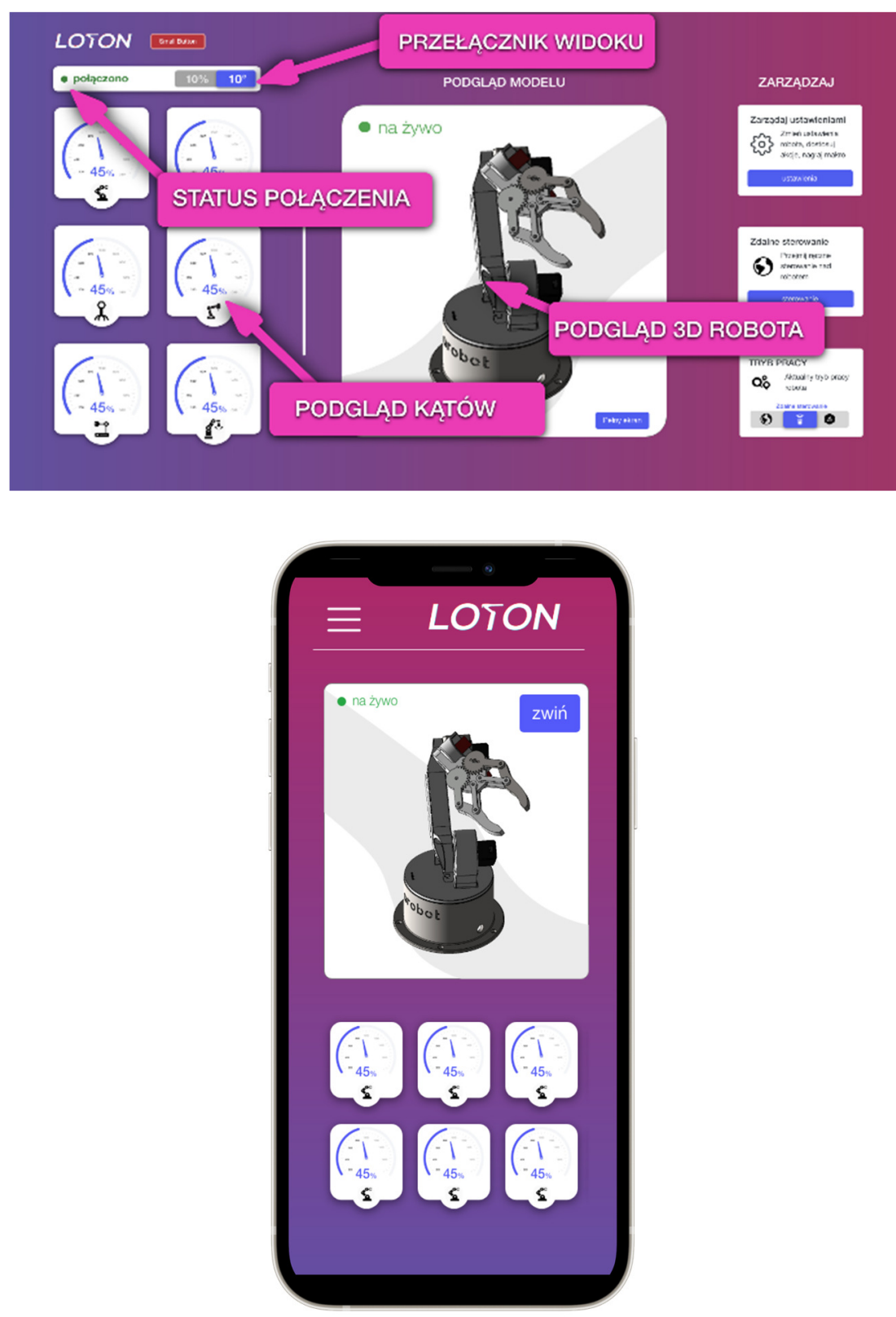

Rysunek 23. Widok interfejsu aplikacji 


\section{Podsumowanie}

Inspiracją do wykonania manipulatora pięcioosiowego była obserwacja robotów przemysłowych pracujących w halach przemysłowych. Podjedliśmy próbę zaprojektowania i wykonania robota który charakteryzuje małym wymiarem oraz stosunkowo niewielkim ciężarem przez co $\mathrm{z}$ powodzeniem może być wykorzystywany do nauki robotyki w szkołach oraz uczelniach technicznych. Przemyślana konstrukcja pozwala na stworzenie zestawu maszyn do samodzielnego montażu. Konstrukcja mechaniczna została zaprojektowana zgodnie z panującymi normami konstrukcyjnymi. Układ elektroniczny pozwala na realizację zadanych ruchów. W planach modernizacji w pierwszej kolejności założono instalację nowych, wymiennych głowic poszerzających zakres roboczy takich jak: elektromagnes, klucz uniwersalny, przyssawka pneumatyczna itd. Aktualizacja software o nowe możliwości, oraz umożliwienie sterowania robotem z dowolnego miejsca na ziemi poprzez umieszczenie strony internetowej na serwerze. Instalacja kamery na głowicy z aktywnym podglądem na stronie, pozwalającej na śledzenie ruchów robota z perspektywę pierwszoosobowej.

\section{LITERATURA}

1. Serwis internetowy: https://www.popsci.com/story/technology/robotic-securitydogs-tyndall-air-force-basel

data dostępu 13.09.2021

2. Serwis internetowy: https://www.kuka.com/pl-pl/produkty-i-ustugi/systemyrobotów/roboty-przemysłowe/kr-1000-titan

data dostępu 13.09.2021

3. Serwis internetowy:

https://roboticsandautomationnews.com/2019/10/09/bwindustrie-installsworlds-first-url6e-collaborative-robot-to-optimise-throughput/26214/ data dostępu 13.09.2021

4. Serwis internetowy: https://news.cision.com/hilti--gt--britain--limited/r/hiltiunveils-bim-enabled-construction-jobsite-robot,c3340064

data dostępu 13.09.2021

5. Serwis internetowy: https://precisionagricultu.re/small-robot-fleets-that-areoperating-in-swarms-in-a-farm-is-the-next-big-innovation-in-agriculture data dostępu 13.09.2021

6. Serwis internetowy: https://gadgets.ndtv.com/science/features/robot-assistedsurgeries-important-india-covid-19-pandemic-5g-surgeon-2268786 data dostępu 13.09.2021

7. Serwis internetowy: https://www.ejinsight.com/eji/article/id/2351065/20200110-pizza-firm-zumesuffers-major-setback-with-its-robot-chefs data dostępu 13.09.2021

8. Serwis internetowy: https://en.wikipedia.org/wiki/Robot_combat data dostępu 13.09.2021

9. Serwis internetowy: https://www.businessinsider.com/irobots-security-anddefense-robots-2014-4?IR=T 
data dostępu 13.09.2021

10. Serwis internetowy: https://www.belrobotics.com/en/blog/choose-a-robot/widearea-robot-mower-a-sizeable-advantagel

data dostępu 13.09.2021

11. Serwis internetowy: https://www.analyticsinsight.net/nanobots-magnifying-thedynamics-of-medical-precision/

data dostępu 13.09.2021

12. Serwis internetowy: https://robohub.org/how-can-swarm-roboticistscontribute-to-and-benefit-from-the-wisdom-of-other-disciplines/ data dostępu 13.09.2021

13. Serwis internetowy: https://www.wired.com/2017/05/the-physics-of-drones/ data dostępu 13.09.2021

14. Serwis internetowy: https://botland.com.pl/serwa-typu-standard/8404-serwopowerhd-lf-20mg-270-standard-6929131202708.html data dostępu 16.09.2021

15. Serwis internetowy: https://rk.edu.pl/pl/python-co-jest-i-do-czego-mozna-gouzyc/ data dostępu 13.09.2021 